\title{
Safety and Pharmacokinetics of Escalating Doses of Human Recombinant Nerve Growth Factor Eye Drops in a Double-Masked, Randomized Clinical Trial
}

\author{
Mauro P. Ferrari - Flavio Mantelli • Marta Sacchetti - Maria Irene Antonangeli • \\ Franca Cattani - Gaetano D'Anniballe - Francesco Sinigaglia • Pier Adelchi Ruffini • \\ Alessandro Lambiase
}

Published online: 11 December 2013

(c) The Author(s) 2013. This article is published with open access at Springerlink.com

\begin{abstract}
Background and Objectives Nerve growth factor (NGF) is a neurotrophin with therapeutic possibilities that extend from the nervous system to the eye. We tested the safety, maximal tolerated dose, pharmacokinetics, and antigenicity of a novel human recombinant NGF (rhNGF) eye-drop formulation in a phase I study.

Methods This prospective, randomized, double-masked, vehicle-controlled trial, sponsored by Dompé SpA (registered as NCT01744704 at ClinicalTrials.gov), enrolled 74 healthy volunteers (24 females, 50 males, age $40.2 \pm 11.8$ years). Subjects were randomized in three cohorts to receive (1) a single eye-drop containing $0.0175,0.175$, or $0.7 \mu \mathrm{g}$ rhNGF; (2) a single ascending dose of rhNGF eye drops three times a day for 1 day (total daily dose 2.1, 6.3,
\end{abstract}

P. A. Ruffini and A. Lambiase contributed equally to this study.

M. P. Ferrari · P. A. Ruffini

Clinical Development, Dompé s.p.a., Milan, Italy

F. Mantelli

IRCCS Fondazione Bietti, Rome, Italy

M. Sacchetti

Cornea and Ocular Surface Unit, San Raffaele Hospital,

Milan, Italy

M. I. Antonangeli · F. Cattani - G. D'Anniballe

Process and Analytical Development, Dompé SpA,

L'Aquila, Italy

F. Sinigaglia

Anabasis Srl, Milan, Italy

A. Lambiase $(\square)$

Department of Ophthalmology, Campus Bio-Medico University

of Rome, Rome, Italy

e-mail: a.lambiase@unicampus.it or $18.9 \mu \mathrm{g}$ ), or vehicle; or (3) a multiple ascending dose of rhNGF eye drops three times a day for 5 days (total dose $10.5,31.5$, or $94.5 \mu \mathrm{g}$ ), or vehicle. Outcome measures included blood chemistry, urinalyses, vital signs, electrocardiograms (ECGs), serum NGF antibodies, ocular and systemic adverse events (AEs), visual acuity, tear function, intraocular pressure, fundus oculi, and ocular symptoms.

Results Administration of rhNGF eye drops did not result in a significant increase of circulating NGF levels and no antidrug antibodies were detected in serum. No serious AEs were recorded, and a few mild, transient ocular AEs related to rhNGF administration were reported only at the highest concentration.

Conclusions rhNGF eye drops were well tolerated, with no detectable clinical evidence of systemic AEs. These results pave the way for the development of clinical trials on rhNGF in ophthalmology.

\section{Introduction}

Nerve growth factor (NGF), the founder and most wellknown member of the family of neurotrophins (NTs), is a pleiotropic factor that extends its biological activity from the central and peripheral nervous systems to the immune, endocrine and visual systems [1].

Signals mediated by NGF are propagated by two distinct receptors: TrkA (a tyrosine kinase receptor) and p75 receptor (a member of the tumor necrosis factor receptor superfamily) [2-4]. The duration and magnitude of NGF signaling depends on the ratio of TrkA and p75 co-distributed on cell surface [4]. From the NGF discovery in the 1950s, increasing evidence has demonstrated that NGF is able to support neuron survival in vitro and during neurodegenerative diseases in animal experimental models and 
in a few patients [5]. In addition, during the last 20 years, pharmaceutical companies have focused on the potential use of NGF for the treatment of peripheral neuropathy such as in diabetes, HIV infection, and following anticancer therapy. In the 1990s, two phase II clinical trials indicated that recombinant human NGF (rhNGF) systemic administration was effective at improving both diabetic polyneuropathy and HIV-related neuropathy, showing as the main side effect a painful sensation at the site of NGF injection [6-8]. However, a large phase III clinical trial of 1,019 patients randomized to receive either rhNGF or placebo for 48 weeks failed to confirm the previous indications of efficacy [9].

At the end of 1990s, we and others have reported on the key role of NGF on the pathophysiology of the ocular surface, showing a role of this NT in the modulation of immune reaction, trophic support, and healing of both cornea and conjunctiva $[10,11]$. As a consequence, the efficacy of topical treatment with murine NGF (mNGF) eye drops was evaluated both in animal models and in patients affected by neurotrophic and autoimmune corneal ulcers [12-15]. In all these cases, therapeutic efficacy was associated with a good safety profile [13-15]. Furthermore, pharmacodynamic studies demonstrated that NGF administered on the ocular surface reaches the ocular posterior segment, opening new perspectives for the treatment of diseases of the optic nerve and retina still lacking effective medical treatments $[16,17]$.

NGF is highly conserved across different species. There is $90 \%$ homology in the amino acid sequence of the mature human and mNGF protein [18]. Considering the evidence of biological activity of mNGF in the eye, a topical formulation of rhNGF produced in Escherichia coli has been developed for the treatment of ocular diseases. Herein we present the results of a phase I clinical trial evaluating the safety of this topical rhNGF eye-drop formulation in healthy subjects.

\section{Results}

Masked review of all available safety information for each treated cohort revealed good tolerability to the study medication, with no clinically significant ocular or systemic changes observed following treatment with the study medication.

Reported ocular adverse events (AEs), as detailed in Tables 1, 2, 3, 4, 5 and 6, were generally transient and mild in intensity. Eight subjects reported non-ocular AEs not related to the study treatment. No serious AEs were recorded during the study.

Subjects with AEs in Cohort 1 were none in the $0.0175 \mu \mathrm{g}(0.5 \mu \mathrm{g} / \mathrm{ml}) \mathrm{NGF}$ group, one in the $0.175 \mu \mathrm{g}$ $(5 \mu \mathrm{g} / \mathrm{ml})$ NGF group (single AE), and one in the $0.7 \mu \mathrm{g}$ (20 $\mu \mathrm{g} / \mathrm{ml})$ NGF group (two AEs).

Subjects with AEs in Cohort 2 were three in the placebo group (six AEs), one in the $2.1 \mu \mathrm{g} / \mathrm{day}(20 \mu \mathrm{g} / \mathrm{ml}$ three times per day) NGF group (five AEs), none in the $6.3 \mu \mathrm{g} /$ day $(60 \mu \mathrm{g} / \mathrm{ml}$ three times per day) NGF group, and two in the $18.9 \mu \mathrm{g} /$ day $(180 \mu \mathrm{g} / \mathrm{ml}$ three times per day) NGF group (three AEs).

Subjects with AEs in Cohort 3 were six in the placebo group (six AEs), eight in the $10.5 \mu \mathrm{g} / 5$ days $(20 \mu \mathrm{g} / \mathrm{ml}$ three times per day) NGF group (14 AEs), six in the $31.5 \mu \mathrm{g} / 5$ days $(60 \mu \mathrm{g} / \mathrm{ml}$ three times per day) NGF group (eight AEs), and seven in the $94.5 \mu \mathrm{g} / 5$ days $(180 \mu \mathrm{g} / \mathrm{ml}$ three times per day) NGF group (11 AEs). Although a significant increase (Cochran-Armitage trend test: $p<0.001$ ) could be observed in the overall AEs between Cohort $1(22.2 \%)$ and Cohort $2(24 \%)$ as compared to Cohort $3(67.5 \%)$, this increase was not considered treatment related since no significant increase was observed in the overall AEs between the placebo and the NGF-treated groups in any cohort (Fisher's exact test: $p>0.4$ )

Regarding the ocular AEs observed in Cohort 1 (Table 1), one patient from the $5 \mu \mathrm{g} / \mathrm{ml}$ NGF group reported a warm feeling in one eye, and one patient from the $20 \mu \mathrm{g} / \mathrm{ml}$ NGF group reported a pressure feeling in both eyes.

In Cohort 2 (Table 3) one patient from the placebo group reported blurred vision, and one patient reported eyelid irritation; in the $20 \mu \mathrm{g} / \mathrm{ml} \mathrm{NGF}$ group, one patient reported blurred vision and a pressure feeling, which were associated with increased fluorescein staining; in the $180 \mu \mathrm{g} / \mathrm{ml}$ NGF group, one patient reported photophobia and ocular irritation.

In Cohort 3 (Table 5) one patient from the placebo group reported ocular pain; in the $20 \mu \mathrm{g} / \mathrm{ml}$ NGF group,
Table 1 Adverse events in Cohort 1

AEs adverse events, $r h N G F$ human recombinant nerve growth factor

\begin{tabular}{llll}
\hline Subjects & $\begin{array}{l}\text { Concentration } \\
\text { (one drop once; } \mu \mathrm{g} / \mathrm{ml})\end{array}$ & $\begin{array}{l}\text { Ocular AEs reported } \\
(\text { no. of patients; severity) }\end{array}$ & Systemic AEs reported \\
\hline 3 rhNGF & 0.5 & None & None \\
3 rhNGF & 5 & Warm feeling, left eye $(n=1 ;$ mild $)$ & None \\
3 rhNGF & 20 & $\begin{array}{l}\text { Feeling of pressure, both eyes } \\
(n=1 ; \text { mild })\end{array}$ & Common cold $(n=1 ;$ mild $)$ \\
\hline
\end{tabular}


Table 2 Summary of adverse events in Cohort 1

\begin{tabular}{|c|c|c|c|c|}
\hline & $0.0175 \mu \mathrm{g} \operatorname{rhNGF}(N=3)$ & $0.175 \mu \mathrm{g} \operatorname{rhNGF}(N=3)^{\mathrm{a}}$ & $0.7 \mu \mathrm{g} \operatorname{rhNGF}(N=3)^{\mathrm{a}}$ & Overall $(N=9)^{\mathrm{a}}$ \\
\hline Subjects with AEs & - & $1(33.3)$ & $1(33.3)$ & $2(22.2)$ \\
\hline Number of AEs & - & 1 & 2 & 3 \\
\hline Subjects with serious AEs & - & - & - & - \\
\hline Subjects discontinued due to AEs & - & - & - & - \\
\hline \multicolumn{5}{|l|}{ Severity (all AEs) } \\
\hline Mild & - & $1(33.3)[1]$ & $1(33.3)[2]$ & $2(22.2)[3]$ \\
\hline Moderate & - & - & - & - \\
\hline Severe & - & - & - & - \\
\hline Total & - & $1(33.3)[1]$ & $1(33.3)[2]$ & $2(22.2)[3]$ \\
\hline \multicolumn{5}{|l|}{ Severity (suspected relationship) } \\
\hline Mild & - & $1(33.3)[1]$ & $1(33.3)[1]$ & $2(22.2)[2]$ \\
\hline Moderate & - & - & - & - \\
\hline Severe & - & - & - & - \\
\hline Total & - & $1(33.3)[1]$ & $1(33.3)[1]$ & $2(22.2)[2]$ \\
\hline \multicolumn{5}{|l|}{ Relationship to study drug } \\
\hline None (intercurrent event) & - & - & - & - \\
\hline Unlikely & - & - & $1(33.3)[1]$ & $1(11.1)[1]$ \\
\hline Possible & - & - & - & - \\
\hline Probable & - & $1(33.3)[1]$ & $1(33.3)[1]$ & $2(22.2)[2]$ \\
\hline Highly probable & - & - & - & - \\
\hline
\end{tabular}

$r h N G F$ human recombinant nerve growth factor, $N=$ number of subjects studied, $A E s$ adverse events

a Data in parentheses denote percentage of subjects with AEs; data in square brackets denote number of AEs

Table 3 Adverse events in Cohort 2

\begin{tabular}{|c|c|c|c|}
\hline Subjects & $\begin{array}{l}\text { Concentration (one drop tid } \\
\text { for } 1 \text { day; } \mu \mathrm{g} / \mathrm{ml} \text { ) }\end{array}$ & $\begin{array}{l}\text { Ocular AEs reported } \\
\text { (no. of patients; severity) }\end{array}$ & Systemic AEs reported \\
\hline $6 \mathrm{rhNGF}$ & 20 & $\begin{array}{l}\text { Blurred vision (moderate) and pressure sensation } \\
\text { (mild), left eye; increased fluorescein staining } \\
\text { (mild-moderate), both eyes }(n=1)\end{array}$ & None \\
\hline $6 \mathrm{rhNGF}$ & 60 & None & None \\
\hline $6 \mathrm{rhNGF}$ & 180 & $\begin{array}{l}\text { Eye irritation ( } n=1 \text {; mild); photophobia ( } n=1 \text {; } \\
\text { mild) }\end{array}$ & Ligament sprain ( $n=1$; severe) \\
\hline 6 placebo & & $\begin{array}{l}\text { Blurred vision (moderate, } n=1 \text { ); eyelid irritation } \\
\quad \text { (moderate } n=1 \text { ) }\end{array}$ & $\begin{array}{l}\text { Headache (mild, } n=2 \text { ); arthritis (mild, } n=1 \text { ); } \\
\text { depression (moderate, } n=1 \text { ) }\end{array}$ \\
\hline
\end{tabular}

tid three times daily, AEs adverse events, $r h N G F$ human recombinant nerve growth factor

one patient reported burning sensation, one reported a pressure feeling, one reported itching, one reported blurred vision, and one reported watering of the eye; in the $60 \mu \mathrm{g} /$ ml NGF group, two patients reported ocular pain and one patient bilateral ocular swelling; in the $180 \mu \mathrm{g} / \mathrm{ml} \mathrm{NGF}$ group, five patients reported eye pain and one reported blurred vision.

In both Cohort 1 and 2 the majority of ocular AEs were reported in the left eye, with some reported in both eyes, and only one $\mathrm{AE}$ was reported in the non-study eye. In
Cohort 3, all the ocular AEs occurred in the eye that had received rhNGF.

More specifically, regarding eye pain, while no patients referred ocular pain in Cohorts 1 and 2, the patients from Cohort 3 who experienced eye pain (Table 5) were one in the placebo group, two in the $60 \mu \mathrm{g} / \mathrm{ml} \mathrm{NGF}$ group, and five in the $180 \mu \mathrm{g} / \mathrm{ml} \mathrm{NGF}$ group. This increase from baseline for the ocular symptom of pain was, however, not statistically significant, even at the highest fractionated multiple dose level of $180 \mu \mathrm{g} / \mathrm{ml}$ (Fisher exact test: 
Table 4 Summary of adverse events in Cohort 2

\begin{tabular}{|c|c|c|c|c|c|}
\hline & $\begin{array}{l}\text { Placebo } \\
(N=6)^{\mathrm{a}}\end{array}$ & $\begin{array}{l}20 \mu \mathrm{g} / \mathrm{ml} \mathrm{rhNGF} \text { tid } \\
(N=6)^{\mathrm{a}}\end{array}$ & $\begin{array}{l}60 \mu \mathrm{g} / \mathrm{ml} \mathrm{rhNGF} \text { tid } \\
(N=6)\end{array}$ & $\begin{array}{l}180 \mu \mathrm{g} / \mathrm{ml} \text { rhNGF tid } \\
(N=7)^{\mathrm{a}}\end{array}$ & $\begin{array}{l}\text { Overall } \\
(N=25)^{\mathrm{a}}\end{array}$ \\
\hline Subjects with AEs & $3(50.0)$ & $1(16.7)$ & - & $2(28.6)$ & $6(24.0)$ \\
\hline Number of AEs & 6 & 5 & - & 3 & 14 \\
\hline Subjects with serious AEs & - & - & - & - & - \\
\hline Subjects discontinued due to AEs & - & - & - & - & - \\
\hline \multicolumn{6}{|l|}{ Severity (all AEs) } \\
\hline Mild & $3(50.0)[3]$ & $1(16.7)[2]$ & - & $2(28.6)[2]$ & $6(24.0)[7]$ \\
\hline Moderate & $2(33.3)[3]$ & $1(16.7)[3]$ & - & - & $3(12.0)[6]$ \\
\hline Severe & - & - & - & $1(14.3)[1]$ & $1(4.0)[1]$ \\
\hline Total & $3(50.0)[6]$ & $1(16.7)[5]$ & - & $2(28.6)[3]$ & $6(24.0)[14]$ \\
\hline \multicolumn{6}{|l|}{ Severity (suspected relationship) } \\
\hline Mild & - & $1(16.7)[1]$ & - & $1(14.3)[1]$ & $2(8.0)[2]$ \\
\hline Moderate & $1(16.7)[1]$ & $1(16.7)[1]$ & - & - & $2(8.0)[2]$ \\
\hline Severe & - & - & - & - & - \\
\hline Total & $1(16.7)[1]$ & $1(16.7)[2]$ & - & $1(14.3)[1]$ & $3(12.0)[4]$ \\
\hline \multicolumn{6}{|l|}{ Relationship to study drug } \\
\hline None (intercurrent event) & $1(16.7)[2]$ & - & - & $1(14.3)[1]$ & $2(8.0)[3]$ \\
\hline Unlikely & $2(33.3)[2]$ & - & - & - & $2(8.0)[2]$ \\
\hline Possible & $1(16.7)[1]$ & $1(16.7)[3]$ & - & $1(14.3)[1]$ & $3(12.0)[5]$ \\
\hline Probable & $1(16.7)[1]$ & $1(16.7)[2]$ & - & $1(14.3)[1]$ & $3(12.0)[4]$ \\
\hline Highly probable & - & - & - & - & - \\
\hline
\end{tabular}

rhNGF human recombinant nerve growth factor, tid three times daily, $N=$ number of subjects studied, AEs adverse events

${ }^{a}$ Data in parentheses denote percentage of subjects with AEs; data in square brackets denote number of AEs

Table 5 Adverse events in Cohort 3

\begin{tabular}{|c|c|c|c|}
\hline Subjects & $\begin{array}{l}\text { Concentration (one drop tid } \\
\text { for } 5 \text { days; } \mu \mathrm{g} / \mathrm{ml} \text { ) }\end{array}$ & $\begin{array}{l}\text { Ocular AEs reported (no. } \\
\text { of patients; severity) }\end{array}$ & Systemic AEs reported \\
\hline 13 rhNGF & 20 & $\begin{array}{l}\text { Burning sensation, left eye ( } n=1 \text {, mild) } \\
\text { Pressure sensation, left eye }(n=1 \text {, mild) } \\
\text { Itching, left eye ( } n=1 \text {, mild) } \\
\text { Blurred vision, left eye ( } n=1 \text {, mild) } \\
\text { Watering, left eye ( } n=1 \text {, mild) }\end{array}$ & $\begin{array}{l}\text { Lower back pain }(n=1, \text { mild }) \\
\text { Pain on venipuncture }(n=1, \text { mild }) \\
\text { Menstrual pain }(n=1, \text { moderate }) \\
\text { Hematuria ( } n=1 \text {, mild }) \\
\text { Abdominal fullness }(n=1 \text {, mild) } \\
\text { Headache ( } n=1 \text {, mild; } n=1, \text { moderate) } \\
\text { Common cold }(n=1, \text { mild })\end{array}$ \\
\hline 9 rhNGF & 60 & $\begin{array}{l}\text { Eye pain }(n=2, \text { mild }) \\
\text { Eye swelling, both eyes }(n=1, \text { mild })\end{array}$ & $\begin{array}{l}\text { Epistaxis }(n=1, \text { mild }) \\
\text { Twitching legs }(n=1, \text { mild }) \\
\text { Joint stiffness }(n=1, \text { mild }) \\
\text { Menstrual pain }(n=1, \text { moderate })\end{array}$ \\
\hline 9 rhNGF & 180 & $\begin{array}{l}\text { Pressure sensation }(n=1, \text { mild }) \\
\text { Eye pain }(n=5, \text { mild }) \\
\text { Blurred vision }(n=1, \text { mild })\end{array}$ & $\begin{array}{l}\text { Painful right knee ( } n=1, \text { moderate }) \\
\text { Common cold }(n=1, \text { mild }) \\
\text { Nasal congestion }(n=1, \text { mild })\end{array}$ \\
\hline 10 placebo & & Eye pain $(n=1$, mild $)$ & $\begin{array}{l}\text { Arthralgia }(n=1, \text { mild }) \\
\text { Pain on venipuncture }(n=1, \text { mild }) \\
\text { Catheter reaction }(n=1, \text { mild }) \\
\text { Oropharyngeal pain }(n=1, \text { mild })\end{array}$ \\
\hline
\end{tabular}

tid three times daily, AEs adverse events, rhNGF human recombinant nerve growth factor 
Table 6 Summary of adverse events in Cohort 3

\begin{tabular}{|c|c|c|c|c|c|}
\hline & $\begin{array}{l}\text { Placebo } \\
(N=10)^{\mathrm{a}}\end{array}$ & $\begin{array}{l}20 \mu \mathrm{g} / \mathrm{ml} \mathrm{rhNGF} \text { tid } \\
(N=12)^{\mathrm{a}}\end{array}$ & $\begin{array}{l}60 \mu \mathrm{g} / \mathrm{ml} \mathrm{rhNGF} \text { tid } \\
(N=9)^{\mathrm{a}}\end{array}$ & $\begin{array}{l}180 \mu \mathrm{g} / \mathrm{ml} \mathrm{rhNGF} \text { tid } \\
(N=9)^{\mathrm{a}}\end{array}$ & $\begin{array}{l}\text { Overall } \\
(N=40)^{\mathrm{a}}\end{array}$ \\
\hline Subjects with AEs & $6(60.0)$ & $8(66.7)$ & $6(66.7)$ & $7(77.8)$ & $27(67.5)$ \\
\hline Number of AEs & 6 & 14 & 8 & 11 & 39 \\
\hline Subjects with serious AEs & 0 & 0 & 0 & 0 & 0 \\
\hline $\begin{array}{l}\text { Subjects discontinued due } \\
\text { to AEs }\end{array}$ & 0 & 0 & 0 & 0 & 0 \\
\hline \multicolumn{6}{|l|}{ Severity (all AEs) } \\
\hline Mild & $6(60.0)[6]$ & $6(50.0)[12]$ & $6(66.7)[7]$ & 7 (77.8) [10] & $25(62.5)[35]$ \\
\hline Moderate & 0 & $2(16.7)[2]$ & $1(11.1)[1]$ & $1(11.1)[1]$ & $4(10.0)[4]$ \\
\hline Severe & 0 & 0 & 0 & 0 & 0 \\
\hline Total & $6(60.0)[6]$ & $8(66.7)[14]$ & $6(66.7)[8]$ & $7(77.8)[11]$ & $27(67.5)[39]$ \\
\hline \multicolumn{6}{|c|}{ Severity (suspected relationship) } \\
\hline Mild & $1(10.0)[1]$ & $2(16.7)[5]$ & $2(22.2)[2]$ & $6(66.7)[7]$ & $11(27.5)[15]$ \\
\hline Moderate & 0 & 0 & 0 & 0 & 0 \\
\hline Severe & 0 & 0 & 0 & 0 & 0 \\
\hline Total & $1(10.0)[1]$ & $2(16.7)[5]$ & $2(22.2)[2]$ & $6(66.7)[7]$ & $11(27.5)[15]$ \\
\hline \multicolumn{6}{|l|}{ Relationship to study drug } \\
\hline None (intercurrent event) & $5(50.0)[5]$ & $6(50.0)[7]$ & $4(44.4)[5]$ & $2(22.2)[3]$ & $17(42.5)[20]$ \\
\hline Unlikely & 0 & $2(16.7)[2]$ & $1(11.1)[1]$ & $1(11.1)[1]$ & $4(10.0)[4]$ \\
\hline Possible & $1(10.0)[1]$ & $2(16.7)[5]$ & $2(22.2)[2]$ & $6(66.7)[7]$ & $11(27.5)[15]$ \\
\hline Probable & 0 & 0 & 0 & 0 & 0 \\
\hline Highly probable & 0 & 0 & 0 & 0 & 0 \\
\hline
\end{tabular}

rhNGF human recombinant nerve growth factor tid three times daily, $N=$ number of subjects studied, AEs adverse events

${ }^{a}$ Data in parentheses denote percentage of subjects with AEs; data in square brackets denote number of AEs

$p=0.0573)$. All patients reported ocular pain to be mild in intensity and only transient in nature, being fully resolved without requiring any concomitant medication.

No evidence of systemic immunogenicity to the topical rhNGF was detected in patients evaluated in any of the cohorts examined (Cohorts 2 and 3 ).

\subsection{Pharmacokinetic Results}

Serum concentrations of NGF at all blood sampling times for all dosed subjects were found not significantly different from basal levels $(34 \pm 14 \mathrm{pg} / \mathrm{ml})$, as measured in the assay serum matrix dosed, with the exception of six subjects-two in Cohort 2 and four in Cohort 3.

Accordingly, the change in NGF serum concentration from baseline resulted to be below the lower limit of quantification of the assay in most of the dosed samples.

Specifically, NGF serum levels were detectable in two patients treated with rhNGF $20 \mu \mathrm{g} / \mathrm{ml}$ (one patient from Cohort 2 and one patient from Cohort 3), two patients treated with rhNGF $60 \mu \mathrm{g} / \mathrm{ml}$ (both from Cohort 3), and two patients treated with rhNGF $180 \mu \mathrm{g} / \mathrm{ml}$ (one patient from Cohort 2 and one patient from Cohort 3).
In these subjects with quantifiable serum levels of NGF, the changes from baseline (day 1) were sporadic and varied from positive to negative values (Fig. 1), thus suggesting an individual physiological fluctuation of the basal levels rather than a treatment-related absorption. This observation is in line with reported data on physiological variability of NGF serum levels [19].

\subsection{Ocular Function Tests}

Best corrected visual acuity and intraocular pressure (IOP) were measured in all cohorts before, during, and after treatment and follow-up, and did not show any significant change from baseline with both experimental treatment and placebo.

Similarly, no alterations of both the anterior and posterior eye segment were observed at the slit-lamp examination during the entire study period. The only exception was a mild and transient bilateral ocular swelling in one patient from Cohort 3 treated with $60 \mu \mathrm{g} / \mathrm{ml}$ rhNGF.

Fluorescein staining showed a mild increase in only one patient from Cohort 2 treated with $20 \mu \mathrm{g} / \mathrm{ml} \mathrm{rhNGF}$.

No significant changes in tear film break-up time were observed in any of the treatment groups. 


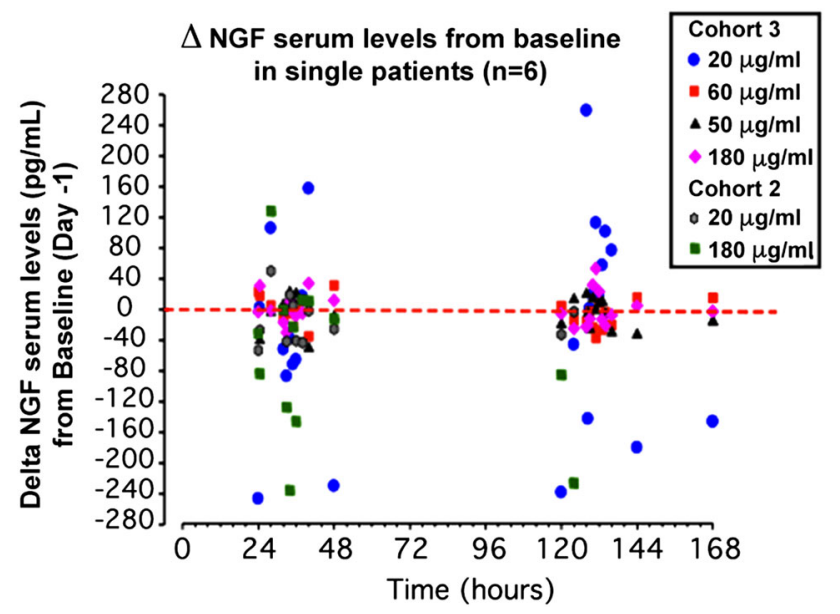

Fig. 1 Changes in serum NGF levels from baseline were observed in two patients from Cohort 2 and four patients from Cohort 3

\section{Discussion}

NGF is a promising therapy for a variety of ocular conditions involving damage or degeneration of the cornea, conjunctiva, retina, or optic nerve, such as neurotrophic keratitis, corneal ulcers, dry eye, retinitis pigmentosa, and glaucoma [1, 10-17, 20-24].

Our findings in the first-in-human study evaluating a topical ophthalmic formulation of rhNGF from 0.5 to $180 \mu \mathrm{g} / \mathrm{ml}$ revealed no local or systemic safety concerns, no evidence of systemic absorption and no evidence of an immune response to the rhNGF protein. Moreover, all doses of rhNGF tested were well tolerated by healthy subjects when administered topically via the ocular route as a single dose (Cohort 1), fractionated single dose (Cohort 2 ), and multiple fractionated doses over 5 days (Cohort 3 ). The majority of AEs were mild in severity and resolved without treatment, and no subjects were discontinued for AEs.

A sequential group ascending-dose design was chosen for safety reasons, as this was the first time a topical ophthalmic formulation of rhNGF had been administered to man. The study started with very low concentrations to further ensure that AEs were to be evaluated at levels that would have had minimal biological activity. In addition, the sentinel study was performed as rhNGF eye drops represent a prototypical first-in-class drug for human therapy, which could potentially have profound physiological effects through binding to cell surface receptors on the eye.

In the first cohort of patients in our study, comprising active- and placebo-treated subjects, we did not observe any ocular or systemic serious AEs following a single administration of rhNGF eye drops ranging from 0.5 to $20 \mu \mathrm{g} / \mathrm{ml}$.
Special attention was paid to identify NGF-induced hyperalgesia, since two previous phase II clinical trials showed that systemic administration of rhNGF triggered a painful sensation at the site of injection as the main side effect [7, 8]. Interestingly, local ocular pain was not reported by any of the subjects from Cohorts 1 and 2, and no significant differences in eye pain were detected between the placebo and NGF groups in Cohort 3. Similarly, no systemic pain was reported.

Following this successful sentinel evaluation, we performed a single ascending-dose study in a second cohort of patients in order to identify the maximum tolerated dose of topical ocular rhNGF. In this second cohort of patients we demonstrated that rhNGF eye drops $180 \mu \mathrm{g} / \mathrm{ml}$ were safe and well tolerated, as we did not observe any serious local or systemic AEs. In fact, only mild-to-moderate transient ocular symptoms possibly related to the study drug were observed in two subjects (including blurred vision and photophobia); however, the same symptoms were also reported in the placebo-treated subjects.

Lastly, following the completion of this single ascendingdose segment of the study, we performed a multiple ascending-dose evaluation. The multiple ascending-dose study was conducted to identify the drug's pharmacokinetic behavior and the maximum tolerated multiple dose, in order to confirm or adjust the pharmacokinetic sampling schedule that was based on the previous single ascending-dose results.

This multiple ascending-dose segment of the study confirmed that rhNGF eye drops represent a safe and well tolerated drug. Specifically, complete ophthalmological examination, laboratory assessments, and vital sign determinations were not significantly influenced by the experimental treatment. The results of pharmacokinetic studies support the lack of significant systemic absorption of rhNGF following ocular treatment in the tested conditions, with no significant changes in basal NGF blood concentration. rhNGF eye drops at the maximum concentration tested three times daily for 5 consecutive days showed an optimal safety profile, with no significant local or systemic AEs reported.

Based on the finding of this phase I safety study, the 'REPARO' study (clinical trial registration number NCT01756456), an 8-week, phase I/II, multicenter, randomized, double-masked, vehicle controlled, parallel group study with a 48- or 56-week follow-up period to evaluate the safety and efficacy of two doses $(10 \mu \mathrm{g} / \mathrm{ml}$ and $20 \mu \mathrm{g} / \mathrm{ml})$ of rhNGF eye drops versus vehicle in patients with stage 2 and 3 of neurotrophic keratitis, has been initiated in Europe.

\section{Methods}

After International Review Board approval, a total of 74 healthy adult male and female volunteers ( 24 females, 50 
males, age $40.2 \pm 11.8$ years) with no notable ocular/ medical history and having normal ophthalmic and general examinations at screening and baseline were enrolled and assigned to one of three study cohorts, each evaluating three ascending rhNGF dose levels. Following informed consent, in each treated subject one eye was randomized to treatment with rhNGF while the fellow eye received a matching vehicle regimen for masking.

Following treatment, patients were evaluated at 10 days (all cohorts) and at 1 month (Cohorts 2 and 3). No concomitant medications were allowed during experimental treatment or follow-up.

One subject withdraw from the study for personal reasons not related to the study treatment, thus 73 completed the study treatment and follow-up periods of 10 or 30 days.

Safety evaluations included a complete ophthalmic exam, a visual analog scale to assess ocular tolerability, vital signs, ECG, urinalysis and routine labs. All AEs were recorded. Plasma samples for pharmacokinetics and immunogenicity were obtained only in parts A and B.

After dosing at each concentration, a review of all safety data was conducted to determine escalation to the next dose level.

\subsection{Study Design}

This is a phase I (ClinicalTrials.gov identifier: NCT01744704), randomised, double-masked, placebocontrolled eye drops administration study of rhNGF in healthy male and female subjects.

This study consists of an ascending single-dose part or sentinel part (first cohort: one drop only), an ascendingdose part (second cohort: three drops only, one drop every $4 \mathrm{~h}$ ), and a multiple ascending-dose part (third cohort: three drops a day, one drop every $4 \mathrm{~h}$, for 5 days). In all subjects both eyes were treated but only one eye was the study eye. Specifically, in Cohort 1 all subjects received rhNGF in the study eye (right or left) according to the randomization list; in Cohorts 2 and 3 all subjects received rhNGF or placebo in the study eye (right or left) according to the randomization list. In all parts of the study the fellow eye (nonstudy eye) was always treated with placebo.

All cohorts of subjects enrolled in this study received three ascending dose levels, as follows:

- Cohort 1 or 'sentinel groups': single dose of one eye drop solution of rhNGF $0.5 \mu \mathrm{g} / \mathrm{ml}$ ( $35 \mu \mathrm{l}$ drop corresponding to $0.0175 \mu \mathrm{g}$ of $\mathrm{rhNGF}$ ), or $5 \mu \mathrm{g} / \mathrm{ml}$ (corresponding to $0.175 \mu \mathrm{g}$ of $\mathrm{rhNGF})$, or $20 \mu \mathrm{g} / \mathrm{ml}$ (corresponding to $0.7 \mu \mathrm{g}$ of rhNGF).

- Cohort 2 or 'single ascending-dose groups': one eye drop every $4 \mathrm{~h}$ (three times daily) at a concentration of $20 \mu \mathrm{g} / \mathrm{ml}$ (total daily dose $2.1 \mu \mathrm{g} \mathrm{rhNGF}$ ), or $60 \mu \mathrm{g} / \mathrm{ml}$ (total daily dose $6.3 \mu \mathrm{g} \mathrm{rhNGF}$ ), or $180 \mu \mathrm{g} / \mathrm{ml}$ (total daily dose $18.9 \mu \mathrm{g}$ ).

- Cohort 3 or 'multiple ascending-dose groups': one drop every $4 \mathrm{~h}$ (three times daily) for 5 consecutive days at a concentration of rhNGF $20 \mu \mathrm{g} / \mathrm{ml}$ (total dose $10.5 \mu \mathrm{g} /$ 5 days), or $60 \mu \mathrm{g} / \mathrm{ml}$ (total dose $31.5 \mu \mathrm{g} / 5$ days), or $180 \mu \mathrm{g} / \mathrm{ml}$ (total dose $94.5 \mu \mathrm{g} / 5$ days).

All subjects received one $35-\mu$ drop of rhNGF at the appropriate concentration (or placebo) in their study eye (right or left) according to the randomization list (and one drop of placebo in the non-study eye).

In the first cohort, each ascending-dose group included three subjects treated with rhNGF.

In the second cohort, each ascending-dose group included six subjects treated with rhNGF and two subjects receiving placebo. In the last cohort, the group receiving the lowest rhNGF concentration $(20 \mu \mathrm{g} / \mathrm{ml})$ included 12 subjects receiving active treatment and four receiving placebo, while the groups treated with rhNGF at 60 and $180 \mu \mathrm{g} / \mathrm{ml}$ included nine subjects per group receiving active treatment and three receiving placebo. The study consisted of a screening period of 20 days before admission followed by a 2-day baseline phase before the first eye-drop application, and an experimental phase of 9-13 days for Cohort 1 subjects, 31-38 days for Cohort 2 subjects, and 36-43 days for Cohort 3 subjects.

Follow-up visits were scheduled at day 10 for Cohort 1 , day 10 (first follow-up) and day 30-37 (second follow-up) for Cohort 2, and at day 15 (first follow-up) and at day 35-42 (second follow-up) for Cohort 3.

\subsection{Safety Assessments}

Safety endpoints included all reported AEs regardless of perceived relationship to study treatment, serious AEs and deaths, discontinuations due to AEs, vision loss, clinical laboratory values, determination of the presence or absence of Anti-Drug Antibodies against NGF, ECGs, and vital signs. Baseline safety assessments were obtained within 2 days before the first treatment. Patients withdrawn due to an $\mathrm{AE}$ were planned to be observed until the event resolved or the patient's condition was stable.

All AEs were coded according to the Medical Dictionary for Regulatory Activities (MedDRA ${ }^{\circledR}$ ) code 5.1.24. AEs that investigators felt were caused by the actual drug were classified as being related to the study drug.

An ophthalmologic examination including measurement of IOP by applanation tonometry was performed on the screening visit, day 1 , day 3 , and day $10 \pm 2$ (Cohorts 1 and 2) and at day 1, day 5 (end of treatment), day 7, and day $15 \pm 2$ in Cohort 3 . Examination of the eye was performed at the slit lamp with inspection of the anterior 
chamber, lens, vitreous body, eyelids, pupils, iris, cornea, retina, and instillation of liquid fluorescein sodium for tear film break-up time and Oxford score measurement at baseline, at day 1 exactly $8 \mathrm{~h}$ after the first eye-drop administration, at day 3 (56 h after the first eye-drop administration), and again at $10 \pm 2$ days (Cohorts 1 and 2). In Cohort 3, slit-lamp examination was performed at day 1 , day 5 (end of treatment), day 7 , and day $15 \pm 2$. Refraction testing and vision testing were performed at the same timepoints using retroilluminated modified FerrisBailey Early Treatment Diabetic Retinopathy Study (ETDRS) charts.

Laboratory assessments (hematology, renal function, hepatic function, electrolytes, and urinalysis), vital sign determinations (blood pressure, pulse rate, temperature, and respiration rate), and body weight measurements were performed at baseline, day 3, and day $10 \pm 2$ (Cohorts 1 and 2), or at day 7 and day $15 \pm 2$ (Cohort 3), and upon early withdrawal, if applicable. Additionally, HIV and hepatitis were tested on the day of the screening visit. An ECG reading interpreted by the patients' internist was obtained at baseline, day 1 and day 3 (Cohorts 1 and 2), and also on days 5 and 7 for Cohort 3 .

\subsection{Pharmacokinetics and Immunogenicity}

Serum samples for pharmacokinetics and immunogenicity were obtained in Cohorts 2 and 3. All these patients received rhNGF and donated blood samples for the analysis of pharmacokinetics.

Serial blood samples were collected pre-dose and after rhNGF eye drops. NGF serum concentrations and antiNGF antibodies were measured (under the Good Laboratory Practice regimen) using photometric enzyme-linked immunosorbent assay (ELISA) methods: briefly, each blood sample was transferred to a polypropylene test tube and kept undisturbed at room temperature (approximately 15-30 $\mathrm{min}$ ) to allow coagulation. The samples were then centrifuged at $1900 \mathrm{~g}$ for $15 \mathrm{~min}$ at $20 \pm 5{ }^{\circ} \mathrm{C}$ and the serum obtained from each sample was distributed to two fresh polypropylene test tubes in two aliquots of $1 \mathrm{ml}$ each, one for rhNGF determination and the other for anti-NGF antibody detection by ELISA methods following the manufacturer's instructions. Briefly, to measure NGF levels in serum we used a commercially available human- $\beta$ NGF-specific ELISA (RayBiotech Inc., Norcross, GA, USA; code ELH-BNGF-001). The standard curve was prepared by using human serum from a commercial supplier (Sigma Aldrich Ltd, St Louis, MO, USA). In order to dose basal NGF levels in this matrix a standard curve ranging from 12.8 to $7812.5 \mathrm{pg} / \mathrm{ml}$ was prepared by diluting rhNGF in the diluent matrix supplied by the kit manufacturer. NGF basal level in the matrix was recorded as $34 \pm 14 \mathrm{pg} / \mathrm{ml}$. Unknown samples were quantified by interpolating their blank-subtracted absorbance $450 \mathrm{~nm}$ values in the reference standard curve ranging from $32.0 \mathrm{pg} / \mathrm{ml}$ to $7812.5 \mathrm{pg} / \mathrm{ml}$.

For the semiquantitative determination of antidrug antibodies against rhNGF in human samples, an ELISA, developed by Harlan Laboratories Ltd (Itingen, Switzerland), was used. Briefly, Maxisorp microtiter plates were coated overnight with saturating concentrations of the test item. After blocking with bovine serum albumin, $100 \mu \mathrm{l} /$ well diluted surrogate standard (rabbit anti-human NGF polyclonal antibody, Abcam, Cambridge, MA, USAproduct code AB9795) or diluted human serum samples, respectively, were transferred to the plate.

Antibodies against the test item in human samples were detected with a goat anti-human horseradish peroxidase (HRP)-coupled IgG secondary antibody (Dianova GmbH, Hamburg, Germany; catalog number 109-035-003), followed by the addition of 3,3',5,5'-tetramethylbenzidine as substrate. The surrogate antibody was detected by a goat anti-rabbit IgG-HRP antibody (Dianova $\mathrm{GmbH}$; catalog number 111-035-003). The reaction was stopped by the addition of Stop Solution. The optical density was read immediately at $450 \mathrm{~nm}$ on a microplate reader. The lower limit of quantification was $1.9 \mathrm{ng} / \mathrm{ml}$, while the upper limit was $125 \mathrm{ng} / \mathrm{ml}$.

In Cohort 2, samples for determination of rhNGF pharmacokinetics were obtained serially before the first dose and over a 3-day period after the administration of the single fractionated dose (for a total of 23 blood samples from time 0 to $56 \mathrm{~h}$ after the initial dose). Samples for the evaluation of rhNGF immunogenicity were obtained before treatment and 30-37 days after the dosing day.

In Cohort 3, samples for determination of rhNGF pharmacokinetics were obtained serially before the first dose and over an 8-day period after the administration of the first single fractionated dose (for a total of 37 blood samples from time 0 to $152 \mathrm{~h}$ after the initial dose). Samples for the evaluation of rhNGF immunogenicity were obtained before treatment and 35-42 days after the first dosing day.

\subsection{Data Analysis}

The safety population included all patients who received at least one dose of study medication. Hematology, liver function, renal function, and electrolyte laboratory parameters were evaluated for the incidence of predefined, clinically significant abnormalities, and for median and mean changes from baseline to last follow-up visit. Urine samples were analyzed for urine protein, urine blood, and urinary albumin-to-creatinine ratio; categorical changes from baseline were evaluated at each timepoint. Although the accuracy of the random collections for urine albumin- 
to-creatinine ratio estimations is inferior to that of the firstmorning urine sample and abnormal values vary with age and gender, an abnormal value was considered to be $>30 \mathrm{mg} / \mathrm{g}$ for this study based. AEs were coded according to the MedDRA ${ }^{\circledR}$ code 5.1.24. AEs also were summarized according to the investigator-determined relationship to the study drug.

The study was neither powered nor designed to analyze efficacy, and no hypothesis testing was planned. Data were analyzed using SAS (version 8.2, SAS Institute, Cary, NC, USA), Fisher's exact test was used to detect any significant difference between groups in specific ocular AEs, and the Cochran-Armitage trend test was used to evaluate the trends in relation to the overall AEs.

Acknowledgments We thank Dr. Ashley Brooks, MBChB, and Dr. Thierry Kamtchoua, MD, of Covance Clinical Research Units for conducting the clinical trial, as well as Dr. Fernàndez Elena of Harland Laboratories Ltd for the analytical determinations, and Guido Fedele of NG Scientific Consulting for statistical analysis.

Financial support The study was supported by Dompé SpA, Milan, Italy.

Conflicts of interest Mauro P. Ferrari, Pier Adelchi Ruffini, Maria Irene Antonangeli, Franca Cattani and Gaetano D'Anniballe are employed by Dompé SpA., Milan, Italy; Francesco Sinigaglia is employed by Anabasis Srl; and Alessandro Lambiase is a medical consultant for Dompé SpA., Milan, Italy.

Open Access This article is distributed under the terms of the Creative Commons Attribution Noncommercial License which permits any noncommercial use, distribution, and reproduction in any medium, provided the original author(s) and the source are credited.

\section{References}

1. Micera A, Lambiase A, Aloe L, Bonini S, Levi-Schaffer F, Bonini S. Nerve growth factor involvement in the visual system: implications in allergic and neurodegenerative diseases. Cytokine Growth Factor Rev. 2004;15:411-7.

2. Chao MV, Hempstead BL. p75 and Trk: a two-receptor system. Trends Neurosci. 1995;18:321-6.

3. Meakin SO, Shooter EM. The nerve growth factor family of receptors. Trends Neurosci. 1992;15:323-31.

4. Yoon SO, Casaccia-Bennefil P, Carter B, Chao MV. Competitive signaling between TrkA and p75 nerve growth factor receptors determines cell survival. J Neurosci. 1998;18:3273-81.

5. Levi-Montalcini R. The nerve growth factor 35 years later. Science. 1987;237:1154-62.

6. McArthur JC, Yiannoutsos C, Simpson DM, Adornato BT, Singer EJ, Hollander H, Marra C, Rubin M, Cohen BA, Tucker T, Navia BA, Schifitto G, Katzenstein D, Rask C, Zaborski L, Smith ME, Shriver S, Millar L, Clifford DB, Karalnik IJ. A phase II trial of nerve growth factor for sensory neuropathy associated with HIV infection. AIDS Clinical Trials Group Team 291. Neurology. 2000;54:1080-8.

7. Apfel SC, Kessler JA, Adornato BT, Litchy WJ, Sanders C, Rask CA. Recombinant human nerve growth factor in the treatment of diabetic polyneuropathy. NGF Study Group. Neurology. 1998;51:695-702.

8. Schifitto G, Yiannoutsos C, Simpson DM, Adornato BT, Singer EJ, Hollander H, et al. AIDS Clinical Trials Group Team 291. Long-term treatment with recombinant nerve growth factor for HIV-associated sensory neuropathy. Neurology 2001;57:1313-6.

9. Apfel SC, Schwartz S, Adornato BT, Freeman R, Biton V, Rendell M, Vinik A, Giuliani M, Stevens JC, Barbano R, Dyck PJ. Efficacy and safety of recombinant human nerve growth factor in patients with diabetic polyneuropathy: a randomized controlled trial. rhNGF Clinical Investigator Group. JAMA. 2000;284:2215-21.

10. Lambiase A, Mantelli F, Sacchetti M, Rossi S, Aloe L, Bonini S. Clinical applications of NGF in ocular diseases. Arch Ital Biol. 2011;149:283-92.

11. Bonini S, Aloe L, Bonini S, Rama P, Lamagna A, Lambiase A. Nerve growth factor (NGF): an important molecule for trophism and healing of the ocular surface. Adv Exp Med Biol. 2002;506:531-7.

12. Lambiase A, Aloe L, Mantelli F, Sacchetti M, Perrella E, Bianchi P, Rocco ML, Bonini S. Capsaicin-induced corneal sensory denervation and healing impairment are reversed by NGF treatment. Investig Ophthalmol Vis Sci. 2012;53:8280-7.

13. Lambiase A, Rama P, Bonini S, Caprioglio G, Aloe L. Topical treatment with nerve growth factor for neurotrophic corneal ulcers. N Engl J Med. 1998;338:1174-80.

14. Lambiase A, Bonini S, Aloe L, Rama P, Bonini S. Anti-inflammatory and healing activities of nerve growth factor in immune corneal ulcers with stromal melting. Arch Ophthalmol. 2000;118:1446-9.

15. Bonini S, Lambiase A, Rama P, Caprioglio G, Aloe L. Topical treatment with nerve growth factor for neurotrophic keratitis. Ophthalmology. 2000;107:1347-52.

16. Lambiase A, Tirassa P, Micera A, Aloe L, Bonini S. Pharmacokinetics of conjunctivally applied nerve growth factor in the retina and optic nerve of adult rats. Investig Ophthalmol Vis Sci. 2005;46(10):3800-6.

17. Lambiase A, Aloe L, Centofanti M, Parisi V, Mantelli F, Colafrancesco V, Manni GL, Bucci MG, Bonini S, Levi-Montalcini R. Experimental and clinical evidence of neuroprotection by nerve growth factor eye drops: implications for glaucoma. Proc Natl Acad Sci USA. 2009;106:13469-74.

18. Ullrich A, Gray A, Berman C, Dull TJ. Human beta-nerve growth factor gene sequence highly homologous to that of mouse. Nature. 1983;30(303):821-5.

19. Serrano T, Lorigados LC, Armenteros S. Nerve growth factor levels in normal human sera. Neuroreport. 1996;8(1):179-81.

20. Mantelli F, Massaro-Giordano M, Macchi I, Lambiase A, Bonini $\mathrm{S}$. The cellular mechanisms of dry eye: from pathogenesis to treatment. J Cell Physiol 2013;228(12):2253-6

21. Coassin M, Lambiase A, Costa N, De Gregorio A, Sgrulletta R, Sacchetti M, Aloe L, Bonini S. Efficacy of topical nerve growth factor treatment in dogs affected by dry eye. Graefes Arch Clin Exp Ophthalmol. 2005;243:151-5.

22. Lambiase A, Coassin M, Tirassa P, Mantelli F, Aloe L. Nerve growth factor eye drops improve visual acuity and electrofunctional activity in age-related macular degeneration: a case report. Ann Ist Super Sanita. 2009;45:439-42.

23. Lambiase A, Aloe L. Nerve growth factor delays retinal degeneration in $\mathrm{C} 3 \mathrm{H}$ mice. Graefes Arch Clin Exp Ophthalmol. 1996;234(Suppl 1):S96-100.

24. Falsini B, Chiaretti A, Barone G, Piccardi M, Pierri F, Colosimo C, Lazzareschi I, Ruggiero A, Parisi V, Fadda A, Balestrazzi E, Riccardi R. Topical nerve growth factor as a visual rescue strategy in pediatric optic gliomas: a pilot study including electrophysiology. Neurorehabil Neural Repair. 2011;25:512-20. 